\title{
sciendo
}

\section{Modern forms of value creation in the global agri-food chain - Perspectives from the facebook ads market}

\author{
Marius CONSTANTIN \\ Bucharest University of Economic Studies, Bucharest, Romania \\ marius.constantin@eam.ase.ro \\ Iuliana Denisa RĂDULESCU \\ Bucharest University of Economic Studies, Bucharest, Romania \\ dennisaradulescu@gmail.com \\ Mile VASIĆ \\ European Marketing and Management Association, Banja Luka, Bosnia and Herzegovina \\ vasic.mile@gmail.com \\ Jean Vasile ANDREI \\ Petroleum - Gas University of Ploiesti, Ploiesti, Romania \\ andrei_jeanvasile@yahoo.com \\ Maria PISTALU \\ Bucharest University of Economic Studies, Bucharest, Romania \\ maria.pistalu@eam.ase.ro
}

\begin{abstract}
Competitiveness has always been considered a vector of innovation that is centered around economic performance; constantly pushing companies to achieve better performance results. In such a modern society deeply marked by digitization, value creation has expanded its scope and it is no longer involving only harnessing customer satisfaction through the quality of the products or services marketed to customers, but it is also involving the permanent digital connection and engagement between the links of any value chain. Digital platforms, including social networks, are major sources of economic concentration where different forms of value emerge. For example, Facebook Inc. runs a business model that involves selling online media space for companies willing to pay money to have consumers of goods and services engage with the ads displayed on Facebook platforms, based on specific group targeting. Taking all of this into consideration, the scientific interest in exploring the nature of an emergent form of value along the chain is implicit. This paper brings its unique contribution to the existing literature concerning the topic of agri-food value chains by providing a niche marketing approach on a paradigm shift at the level of the nature of value generated in the chain in the case of highly digitized societies. The research objective was to bring the sustainability factor into the spotlight of the analysis concerning the paradigm shift of the nature of the value generated in the agri-food value chain. Research results show that some multinational corporations active in the Romanian agri-food sector use the Facebook Ad Market to reach consumers and call for them to engage in activities specific to building a sustainable agri-food system. Thus, by engaging in such activities, consumers feel that they contribute to the corporations' effort in achieving sustainability. Consequently, a different form of value is generated along the chain.
\end{abstract}

Keywords: global agri-food value chain; value co-creation; digital engagement; Facebook Ads Market. 


\section{Introduction}

The agriculture and agri-food system has become increasingly industrialized and globalized over the last three decades. The global economy has provided companies all around the world the opportunity for substantial economic growth, even though. The current configuration of the global agri-food value chain is mainly driven by different types of agri-food multinational companies: agri-business giants, diverse food manufacturers, numerous global retailers, varied fast-food franchises. Such global giants can influence the course of agri-food products, from production to consumption, through tight coordination across the value chain. The contemporary global agrifood value chain properly functions through the interaction between its many chain links.

Over the course of time, globalization has generated an intensification of the labor division and the global dispersion of production components, especially in the spirit of an exacerbated race for economic competitiveness.

Highly economically-competitive companies are shaped in terms of the business model and undertaken principles by the process of adding value along each stage through which a product or service is subject to - from producer to consumer. Therefore, the significance of adding value to a product or service resides in that value creation is one of the factors that make enterprises economically competitive. Economic competitiveness can be challenging for companies when they possess the same capabilities, which is why value creation is an imperative source of competitive advantage, heavily reliant on the cycles of value capture, creation, and delivery.

Digitization has been contributing to the paradigm change in relation to how the nature of value is perceived (Blaschke et al., 2019; Ritter and Pedersen, 2019; Ahn, 2020). Some of the activities carried out by important links of the global agri-food value chain are deeply influenced by the use of information systems. These solutions play an increasingly dominant role in generating innovation and in reshaping and co-creating value along the chain (Lusch and Nambisan, 2015), beyond the physical boundaries. As a result, digital technology causes an increase in the integration of digital solutions in processes carried out by many links from various chains (Ardito et al., 2019).

The emergence of globally-connected digital infrastructures through information systems involves, among others, a paradigm change regarding value co-creation (Jayashankar et al., 2019).

Considering the rising global appetite for digitization and the existing broad literature concerning the topic of agri-food value chains, the scientific interest for exploring the nature of an emergent form of value is implicit. This paper complements the existing literature concerning the topic of agri-food value chains by bringing a unique contribution, referring to the special focus of this paper - a paradigm shift at the level of the nature of value generated in the chain in knowledgebased societies. Moreover, this research expands the field of knowledge with a niche marketing approach on how multinational agri-food corporations engage with the last agri-food chain link in a global digital ad market. Additionally, the sustainability factor is brought to the spotlight.

The objective of this research is to examine the nature of the value generated in the digital space, based on the dynamics between agri-food value chain links in the Facebook Ads Market. Even though the digital market is global - international buyers can purchase ads and display them in any country where Facebook users exist, this research is focused on the engagement with Romanian customers. Additionally, digital engagement is studied only in the case of the three major multinational corporations active in the Romanian agri-food market.

This paper follows a traditional format. In the first part of the paper, a literature review was carried out, consisting of two subchapters: one concerning traditional approaches to agri-food value chains, while the other is focused on explaining the nature of a modern form of added-value along the agri-food chains, referring to the digital engagement between consumers and other chain links. 
The literature review chapter is followed by the research methodology chapter. The latter is succeeded by the section dedicated to the research results discussion. In the last part of the paper, the conclusions of this research are highlighted, as well as the limitations. Not only that but further research directions are also suggested.

\section{Literature review}

\section{A. Traditional Approaches to Agri-food Value Chains and Value}

The traditional concept of the value chain was first described and made popular by Michael Porter in his work called "Competitive Advantage: Creating and Sustaining Superior Performance" (1985). This concept refers to the generic value-adding activities carried out by organizations. Added-value can be generated during many stages of production: inbound/outbound logistics, operations, logistics, marketing and sales, services/maintenance, administrative activities, procurement, infrastructure management, human resource management, research, and development activities. The concept of value chain acts as a powerful analysis tool for managers and decision-makers regarding strategic planning. Although value chains are complex and differ based on sectors, they have many layers, specific to the nature of the sector. The ultimate goal of analyzing a value chain is to maximize value creation, minimize costs, and harness the sustainability and just factors in the case of all links involved along the value chain (Newell \& Mulvaney, 2013; Fonseca and Azevedeo, 2020).

In a guideline prepared for FAO, Attaie and Fourcadet (2003) define a value chain as the economic system consisting of various links, such as producers, distributors, suppliers - all engaging in the market with the aim of selling products to the final link of the chain: the consumer. Value chains imply the full activities range required to produce and sell products or services, starting from conception through various production phases, only in the end to reach consumers. Kotler et al. (2006) argue that value is linked to consumers' feelings of pleasure or disappointment caused by comparing the quality of a product or service concerning the consumers' expectations.

The global agri-food system is highly competitive in contemporary economies and has become increasingly complex due to the many changes coming from the consumer demand-side, due to the intensification of complex food standards related to food safety (Nguyen and Jolly, 2020; Paun and Ivascu, 2020) and food quality (Minten et al., 2013), due to the permanent and galloping advances of technology (Zhao et al., 2019; Saurabh \& Dey, 2021), and due to various changes in the structure of the system, influenced by the link dynamics along the agri-food value chain highly sensitive during times of crisis (Arouna et al., 2020; Christiaensen et al., 2020; Ignat \& Constantin, 2020).

Value creation or value-adding in the agri-food chains occurs when a firm carries out activities that determine changes to the physical state of any agricultural commodity or improve its quality through production, handling, marketing, and other activities (Filippi \& Chapdaniel, 2016; Cucagna \& Goldsmith, 2018; Andrei et al., 2020). The outcome of adding value is that this complex process expands and improves the customer experience with the product, while each component of the chain generates profit. However, the end goal is not only to maximize consumer experience or chain links' profit but to respect the natural capital by producing and consuming sustainably (Govindan, 2018; Dinu et al., 2020; Varela et al., 2021).

The meaning of value has expanded beyond the traditional approach. In the literature, chain value is analyzed in different situations - through the lens of the innovation value chain, the shared value chain, and even through a creative design-driven dynamic value chain (Simatupang et al., 
2018). Added-value has always been advocated as a strategy for achieving commercial competitive advantage (Walters et al., 2002). Processes that generate intangible added-value for a final product foster sustainable competitive advantage and can even define a brand (de Chernatony et al., 2000). In this context, value can no longer be considered without the role of digital innovations in marketing or on the value chain and business models in general (Sahut et al., 2019). Successful companies do not simply add value - but they redefine and reinvent it (Bitici et al., 2004).

\section{B. Digital Engagement - A Modern Form of Added-Value along the Chain}

The value of a product or service is not directly linked to production costs, but it is directly linked to a set of judgments made by the end consumers' level of satisfaction obtained through the usage or consumption of that respective product or service (Lind, 2004). In this context, it could be partly misleading to consider that changes in the production process would directly lead to an increase of the added value for a product or service (Forbes and Wield, 2002). Instead, innovations through research, from product/service concept to consumption, could actually lead to better quality, which in the end could turn into increased consumer satisfaction and a higher price for that product or service. In this equation, the precondition is that customers value the enhanced quality and are willing to pay more for the improved product or service.

Recent contributions to the literature consist of papers approaching the topics of value cocreation and topics related to the emergence of a new form value, referring to the one generated through digital methods (King et al., 2016; Rodgers and Thorson, 2018; Xie et al. 2016; Balaji \& Roy, 2016; Hein et al., 2019; Sorensen et al., 2017; Kovalenko and Kuzmenko, 2020).

King et al. (2016) raised awareness over the need for value innovation and called for management and stakeholders to invest resources into digital projects since a clear demand was observed coming from consumers. Rodgers and Thorson (2018) noted that although digital engagement has been previously addressed in the literature, the topic of value co-creation is still subject to be empirically examined. They approached the topic of digital engagement as the act characterized by consumers interacting with any brand that aims to strengthen the emotional, psychological, or physical connection with consumers through digital means.

Xie et al. (2016) argue that value co-creating through digital engagement is challenging for the traditional value creation logic, which implies that value is transferred from firms to customers. In the case of the emergent value co-creation logic, value is consumer-centric and co-created by both enterprises and consumers (Grönroos \& Voima, 2012). Value co-creation requires joint actions carried out by both consumers and an enterprise through direct interactions, which can also happen in the digital space. Therefore, both the enterprise and consumers are the main direct beneficiaries of this cooperation. Kumar et al. (2010) defined the concept of "customer engagement value" to describe the value generated by an enterprise specialized in co-creation processes. Such a process is characterized by four main components: consumer lifetime value (referring to purchasing patterns), consumer influencer value (referring to the likelihood of intensifying wordof-mouth communication among existing and potential customers), consumer referral value (reaching and obtaining new customers), and consumer feedback value (reflecting expectations, suggestions for improvement and innovation).

Additionally, the literature contains a lot of work dedicated to topics related to online advertising. Some research papers were designed to study the factors affecting consumer attitudes and behaviors via Facebook advertising (Celebi, 2015), the user-exposure behavior in relation to online advertising on Facebook (Galán et al., 2019), the relationship between revenue and 
Facebook traffic (Myllylahti, 2018) and even methods to attract digital engagement via comments on Facebook, while considering financial performance (Yoon et al., 2018).

Since online advertising generates a lot of income for Facebook, Inc. and a billion individuals are active on its platforms (Mosquera et al., 2019), this paper's focus is Facebook specifically.

\section{Methodology}

Piller et al. (2012) argued in their research for the emergence of value co-creation due to the skyrocketing rise in popularity of social media platforms, especially Facebook. Not only that, but taking social media platforms into consideration when carrying out research on this new form of added-value along the chain would bring at least an interesting point of view on the specific analyzed subject. In conjunction with the objective of this research, developing a niche marketing analysis on the nature of the co-created value through the digital engagement of multinational agrifood corporations with consumers is reliant on the transparent, open-access data available online from Facebook Ads Market.

Facebook Ad Library is the source of the data used in carrying out this research. According to Facebook Inc. (2021), the company's open-access ad library provides advertising transparency by offering a comprehensive collection of all active ads running from across Facebook apps and platforms. In the case of this research, the Facebook Ad Library was accessed in February 2021.

Table 1 was elaborated with the aim of briefly describing the selected multinational corporations active in the Romanian agri-food sector. Moreover, this table contains Facebookrelated identification details about the analyzed corporations.

Table 1. Selected multinational corporations active in the Romanian agri-food sector

\begin{tabular}{|c|c|c|c|c|}
\hline $\begin{array}{l}\text { Multinational } \\
\text { Corporation Active } \\
\text { in the Romanian } \\
\text { Agri-food Sector }\end{array}$ & $\begin{array}{l}\text { Short Description } \\
\text { of the Corporation }\end{array}$ & $\begin{array}{l}\text { Facebook Page } \\
\text { Name, ID and } \\
\text { Lauch Date } \\
\text { in Romania }\end{array}$ & $\begin{array}{c}\text { Number } \\
\text { of Persons who } \\
\text { Like the } \\
\text { Facebook Page }\end{array}$ & $\begin{array}{l}\text { Analyzed Facebook } \\
\text { Ad IDs from the } \\
\text { Facebook Open } \\
\text { Ad Library }\end{array}$ \\
\hline Carrefour S.A. & $\begin{array}{l}\text { French retailer active } \\
\text { in Romania since } 2001\end{array}$ & $\begin{array}{c}\text { Carrefour } \\
170252536439294 \\
\text { Launched in } 2012\end{array}$ & $11,559,630$ & $\begin{array}{c}454800849032082 \\
1754256791417859\end{array}$ \\
\hline $\begin{array}{l}\text { Lidl Stiftung \& Co. } \\
\text { KG, part of the } \\
\text { Schwarz Gruppe }\end{array}$ & $\begin{array}{l}\text { German discounter } \\
\text { active in Romania } \\
\text { since } 2011\end{array}$ & $\begin{array}{c}\text { Lidl Romania } \\
185899758126310 \\
\text { Launched in } 2011\end{array}$ & $2,152,048$ & $\begin{array}{c}437895227561330 \\
1972490279555593\end{array}$ \\
\hline $\begin{array}{c}\text { Selgros, owned by } \\
\text { Transgourmet } \\
\text { Holding AG }\end{array}$ & $\begin{array}{l}\text { Cash \& carry chain } \\
\text { active in Romania } \\
\text { since } 2001\end{array}$ & $\begin{array}{c}\text { Selgros Romania } \\
274362715946707 \\
\text { Launched in } 2011\end{array}$ & 504,886 & $\begin{array}{l}484942076241375 \\
433116554558429\end{array}$ \\
\hline
\end{tabular}

Source: Authors' own design based on Facebook Open Ad Market Library, accessed February 2021 (https://www.facebook.com/ads/library/).

Considering that sustainability factor was brought into the spotlight of this research paper, the ads selected from the Facebook Ad Library were the ones calling for consumer action concerning reducing food waste, empowering green and local food production patterns, fostering the transition toward the circular economy and other actions calling for sustainability in general.

Facebook media buying in the case of Carrefour, Lidl, and Selgros was analyzed through the lens of the co-created value along the global agri-food value chain. Some of the agri-food 
products sold by the previously mentioned corporations were produced in foreign countries and sold to Romanian consumers. The co-created value was generated by the multinational corporations active in the Romanian agri-food sector and by the chain's final link: the consumer who got the ad delivered by Facebook, Inc. Along the global agri-food chain, traditional monetary added-value might not have been generated only in the case of Romanian links, but also in the case of other links who carried out specific activities of value generation outside the borders of Romania. However, the co-created value was purposefully designed by the media buyers to be generated between the three analyzed multinational corporations and Facebook users from Romania.

\section{Results and discussions}

In February 2021, Carrefour was paying Facebook to have two ads displayed to Romanian users concerning their "Act for Food" program, which launched in September 2018. Carrefour (2021) claims that through the implementation of this program, the corporation "mobilizes its employees, agricultural partners and all stakeholders to make healthy, quality, sustainably produced food accessible to everyone". Figure 2 is a concatenation of the ads designed financially supported by Carrefour with the aim of raising awareness over the "Act for Food" program.

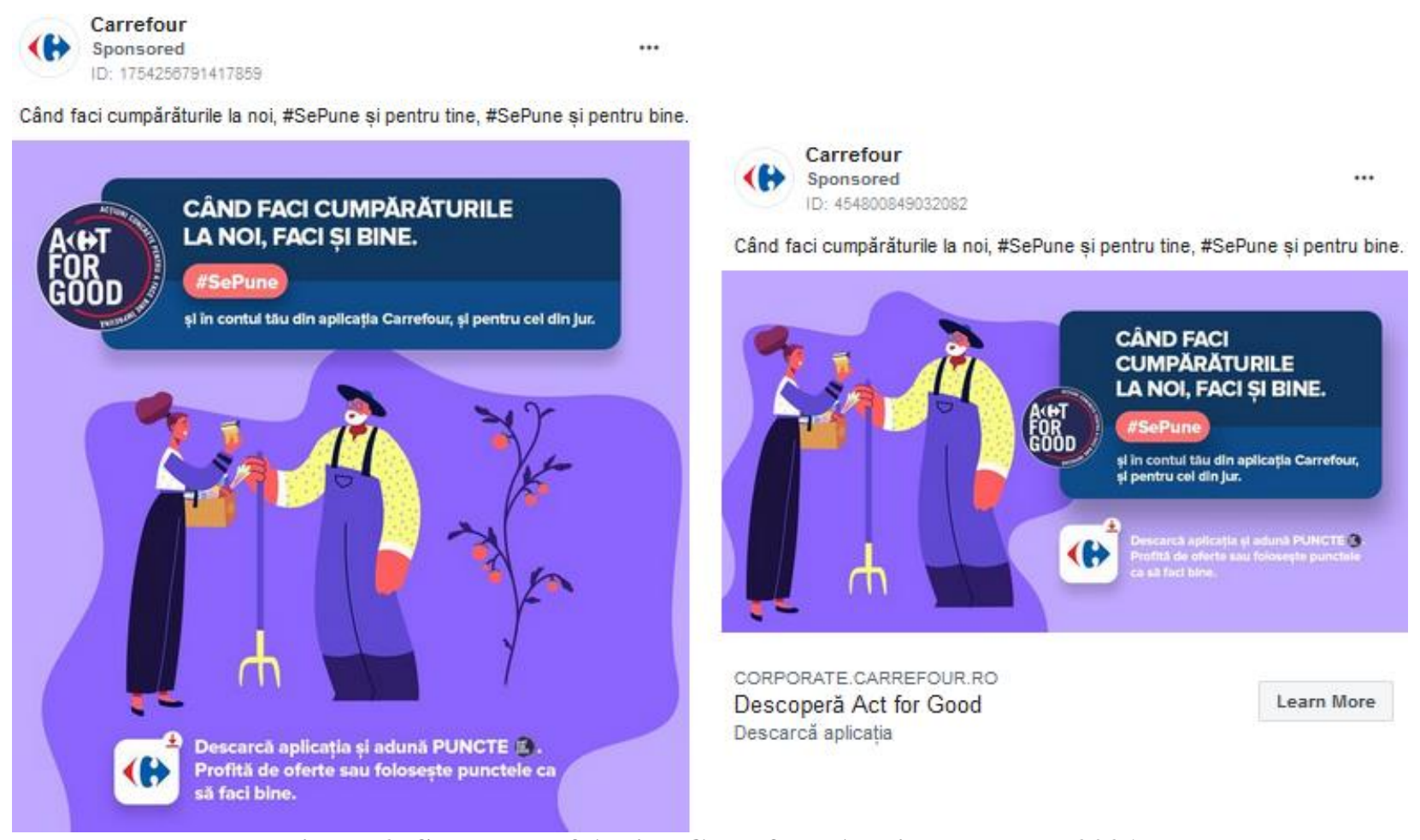

Figure 2. Snapshot of Active Carrefour Ads in February 2021

Source: Authors' concatenation of public information collected from Facebook Ad Library in February 2021 (https://www.facebook.com/ads/library/? ad_type=all\&country=RO\&view_all_page_id=170252536439294).

Carrefour argues that consumers need to pay more attention to what is on their plates, especially since the health of the capital natural is at stake if consumption behaviors are not sustainable. The French multinational corporation encourages its customers to choose healthy locally and sustainably produced food, making it possible to combat global warming and harness the local economy at the same time. Additionally, Carrefour (2021) claims that the corporation 
strives to grow the sales of fresh products especially in the case of those coming from local supply chains. Not only that, but Carrefour (2021) also states that they encourage responsible practices intending to protect biodiversity.

The co-created value along the agri-food chain is beyond the monetary added value. Carrefour bonds with Facebook users from Romania on a much deeper and meaningful level. Their initiative calls for sustainable agri-food production and consumption patterns and contributes to many of the United Nation's (2015) Sustainable Development Goals.

\section{sine \\ Lidl Romania \\ Sponsored \\ D: 437895227561330 \\ E timpul rezoluțiilor \#PentruUnViitorlaaiBun! คิ}

Noi am inclus pe lista noastră de rezoluții să contribuim la atingerea unuia dintre cele 17 obiective de dezvoltare durabilă ale Organizatiei Natiunilor Unite, acela de a reduce la jumătate cantitatea de alimente risipite la nivel individual ș in industria de retail și reducerea cantităților de produse alimentare care devin pierderi in lantul de aprovizionare și procesare. 00

Poți vedea și alte angajamente pe care ni le asumăm, in noul nostru Raport de Sustenabilitate: https://bit.ly/300mDI1
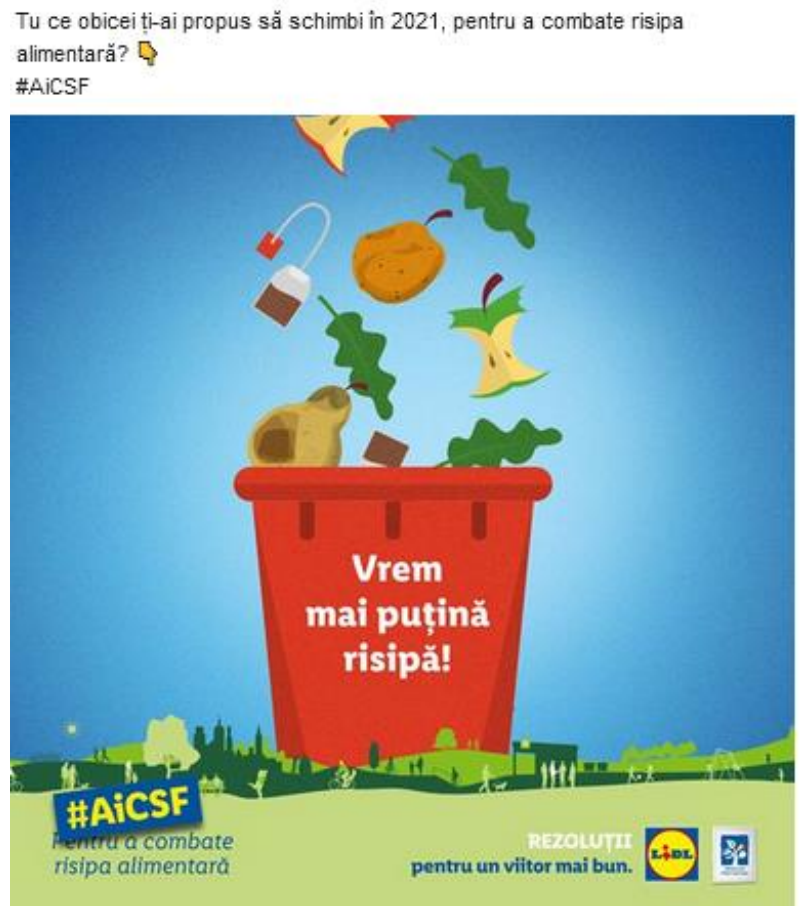

Figure 2. Snapshot of Active Lidl Romania Ads in February 2021

Source: Authors' concatenation of public information collected from Facebook Ad Library in February 2021 (https://www.facebook.com/ads/library/? ad_type=all\&country=RO\&view_all_page_id=185899758126310).

Lidl is another multinational corporation active in the Romanian agri-food sector that was paying Facebook to have ads displayed to Romanian users in February 2021. Similar to Carrefour's initiative, Lidl's call is specifically focused on encouraging consumers to reduce food waste. According to Lidl's sustainability strategy, the corporation aims to make food accessible to everyone, in accordance with United Nation's (2015) Sustainable Development Goals, as well as ensuring that the food is produced, sold, and consumed in such a way that it benefits not only the 
corporation but producers, people and the planet at the same time (Lidl, 2021). The German discounter strives to minimize its food surplus by preventing it in the first instance and, if not possible, Lidl works to have it redistributed in agri-food chain. "Feed It Back" and "Waste Not" are two of the programs launched by Lidl to minimize its food surplus. By paying Facebook to have ad ID 1972490279555593 (included in Figure 2) displayed to Facebook users from Romania, Lidl generated 208 reactions, 14 comments, and 3 shares (accessed on 13 February 2021). Moreover, the corporation co-created value with Facebook users in a sustainable manner.

PICBE | 818
Selgros Romania

Sponsored

10: 433116554558429

\section{Stiați că?}

- Produsele BIO sunt același lucru cu produsele ECO sau organice? Motivul pentru care există trei denumiri distincte, este că fiecare din ele reprezintă tara in care sunt folosite.

- Pentru ca un producător să aibă dreptul de a cultiva produse eco, bio, organice, el trebuie să detoxifieze pământul/mediul de creștere timp de cel putin doi ani.

- Containerele și ambalajele trebuie să indeplinească criteriile de organicitate.

- Fructele și legumele BIO nu pot fi culese crude și coapte apoi artificial in timpul transportului.

\#HranestePasiunea \#SelgrosRomania \#BIO

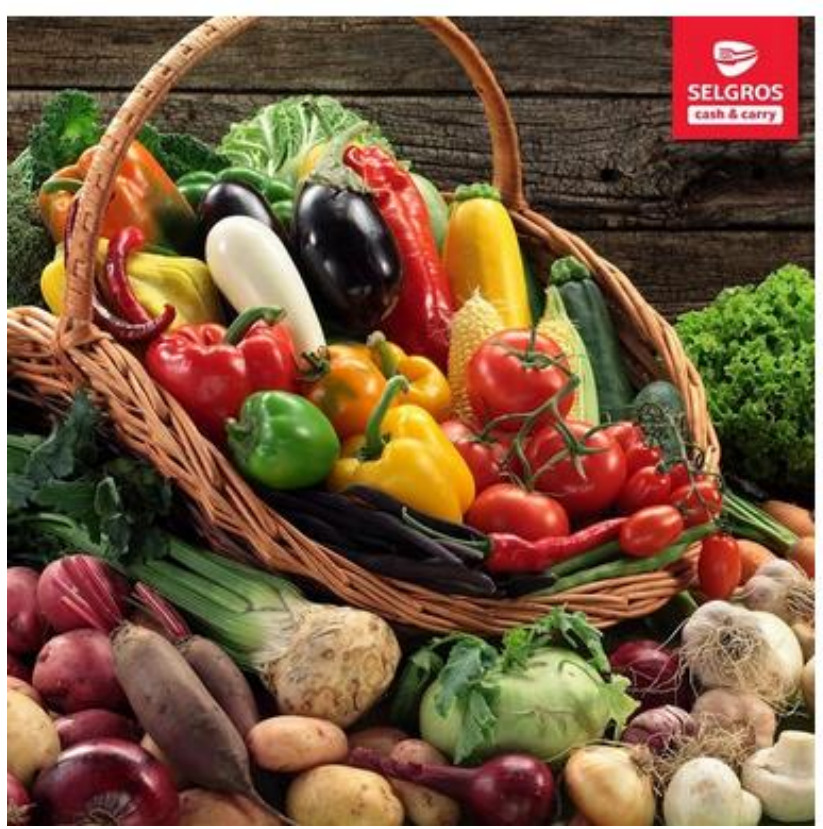

Selgros Romania

Sponsored

ID: 484942076241375

Preocuparea pentru sănătate și dorinta de a urma un stil de viată echilibrat, a inceput să câştige din ce in ce mai mult spațiu in viața consumatorului. Pentru că și noi sustinem aceste valori, vă invităm să descoperiti în magazinele Selgros gama variată de produse BIO.

\#MananciPurSiSimpluBio \#HranestePasiunea \#SelgrosRomania

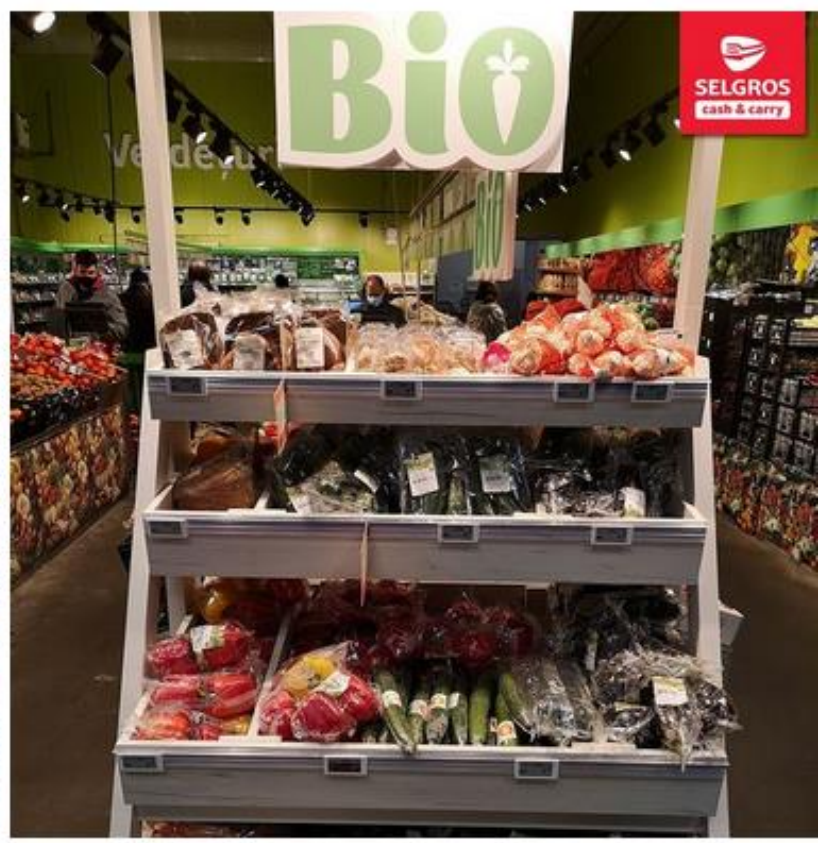

Figure 3. Snapshot of Active Selgros Romania Ads in February 2021

Source: Authors' concatenation of public information collected from Facebook Ad Library in February 2021 (https://www.facebook.com/ads/library/? ad_type=all\&country=RO\&view_all_page_id=274362715946707).

The ads financially supported by Selgros empower a healthy consumer lifestyle, as suggested by the concatenated messages displayed in Figure 3. Regarding digital engagement, ad ID 484942076241375 received 211 reactions and 26 shares and ad ID 433116554558429 received 110 reactions, 1 comment, and 6 shares. Through the means of buying digital space from Facebook, Selgros raised awareness over important factors that make food consumers well-informed. In ad ID 433116554558429, Selgros brings the difference between the concept of bio, eco, and organic 
products into the spotlight. Co-creating value with Facebook users in the case of Selgros involves building bridges to knowledge concerning sustainability and healthy consumption behaviors. With this approach, Selgros brings consumers closer to the agri-food producers who practice environmentally-friendly farming and processing. Theoretically, this is a win-win situation, but there are more than two sides involved - the global agri-food chain is much more complex. Selgros facilitates eco-friendly producers to continue producing sustainably, consumers are pushed on the path to a healthy lifestyle and Facebook earns income for displaying ads on its platforms.

\section{Conclusions}

The agri-food system has been subject to profound changes in the context of an exacerbated process of globalization and digitization. As a result, economic competitiveness is still an actual topic in the literature concerning agri-food value chains, but it can no longer be considered without adding the sustainability and value co-creation factors into the equation.

Traditionally, the value chain framework emerged as a marketing management tool focused on the analysis of the drivers of business success and value generation. In the chain, each stage preceding consumption seeks to offer maximum value to the consumer while improving economic performance in the case of the links involved in value creation. Obtaining a competitive advantage does not imply working alone, but rather working within a collaborative value chain framework where companies action most efficiently together, as members of the chain.

Value creation involves customers' creation of value-in-use. However, a new form of value has emerged in the value chain. Digitization has been contributing to the paradigm change regarding the nature of added value and how it is perceived by consumers. Information systems and solutions have been generating innovating and have been reshaping the nature of value - they have contributed to value co-creation, a function of interaction. One can notice the pivotal role of the interaction between all the links involved in the agri-food chain in order to maximize value and to even co-create value through the joint interaction of the links on digital information systems and platforms. Exploring the nature of these phenomena was the objective of this study.

With particular attention paid to the sustainability factor, a niche marketing analysis was carried out in this paper on the nature of the co-created value through the digital engagement of multinational agri-food corporations with consumers. The co-creation of value was studied based on transparent, open-access data available online in the Facebook Ad Library.

In the case of the three analyzed multinational corporations active in the Romanian agrifood value chain, the co-created value was beyond the monetary added value. Carrefour, Lidl, and Selgros engaged with the Facebook users from Romania in the spirit of empowering the joint collaboration in the race for meeting the Sustainable Development Goals from the 2030 Agenda for Sustainable Development.

This research can be extended by improving the analysis framework concerning value cocreation. Agri-food chain links can be studied based on a much smaller scale in the case of regional or local approaches on the paradigm shift regarding the nature of the added value in rural areas. One of the limitations of this research is that the only information solution considered for analysis was the one developed by Facebook. Future research should be considered in relation to the rest of the most popular digital engagement platforms. 


\section{Funding}

This paper was co-financed by The Bucharest University of Economic Studies during the PhD program. The funder had no role in the design of the study; in the collection, analyses, or interpretation of data; in the writing of the manuscript, or in the decision to publish the results.

\section{References}

Ahn, S.-J. (2020). Three characteristics of technology competition by IoT-driven digitization.

Technological Forecasting and Social Change, 157, 120062, https://doi.org/10.1016/ j.techfore.2020.120062.

Andrei, J. V., Popescu, G. H., Nica, E., \& Chivu, L. (2020). The impact of agricultural performance on foreign trade concentration and competitiveness: empirical evidence from Romanian agriculture, Journal of Business Economics and Management, 21(2), 317-343, https://doi .org/10.3846/jbem.2020.11988.

Ardito, L., Petruzzelli, A. M., Panniello, U., \& Garavelli, A. C. (2019). Towards Industry 4.0, Business Process Management Journal, 25(2), 323-346, https://doi.org/10.1108/bpmj-042017-0088.

Arouna, A., Soullier, G., Mendez del Villar, P., \& Demont, M. (2020). Policy options for mitigating impacts of COVID-19 on domestic rice value chains and food security in West Africa. Global Food Security, 100405, https://doi.org/10.1016/j.gfs.2020.100405.

Attaie, H., \& Fourcadet, O. (2003). Guildeline for Value Chain Analysis in the Agri-Food Sector of Transitional and Developing Economies. Prepared for Food Agriculture Organisation of the United Nations, ESSEC Business School France, MBA in International Agri-Food Management.

Balaji, M. S., \& Roy, S. K. (2016). Value co-creation with Internet of things technology in the retail industry, Journal of Marketing Management, 33(1-2), 7-31, https://doi.org/ 10.1080/0267257x.2016.1217914.

Bititci, U. S., Martinez, V., Albores, P., \& Parung, J. (2004). Creating and managing value in collaborative networks, International Journal of Physical Distribution \& Logistics Management, 34(3/4), 251-268, https://doi.org/10.1108/09600030410533574.

Blaschke, M., Riss, U., Haki, K., \& Aier, S. (2019). Design principles for digital value co-creation networks: a service-dominant logic perspective, Electronic Markets, https://doi.org/ 10.1007/s12525-019-00356-9.

Carrefour. (2021). Making "Eating Better" Accessible to Everyone. Carrefour, https://www. carrefour.com/en/group/food-transition.

Celebi, S. I. (2015). How do motives affect attitudes and behaviors toward internet advertising and Facebook advertising?, Computers in Human Behavior, 51, 312-324, https://doi.org/ 10.1016/j.chb.2015.05.011.

Christiaensen, L., Rutledge, Z., \& Taylor, J. E. (2020). Viewpoint: The future of work in agri-food, Food Policy, 101963, https://doi.org/10.1016/j.foodpol.2020.101963.

Cucagna, M. E., \& Goldsmith, P. D. (2018). Value Adding in the Agri-Food Value Chain, International Food and Agribusiness Management Review, 21(3), 293-316, https://doi.org/ 10.22004/ag.econ.269674.

de Chernatony, L., Harris, F., \& Dall'Olmo Riley, F. (2000). Added value: its nature, roles and sustainability, European Journal of Marketing, 34(1/2), 39-56, https://doi.org/10.1108/ 03090560010306197. 
Dinu, M., Pătărlăgeanu, S. R., Petrariu, R., Constantin, M., \& Potcovaru, A.-M. (2020). Empowering Sustainable Consumer Behavior in the EU by Consolidating the Roles of Waste Recycling and Energy Productivity. Sustainability, 12(23), 9794, https:// doi.org/10.3390/su12239794.

Facebook Inc. (2021). Facebook Ad Library. https://www.facebook.com/ads/library/.

Filippi, M., \& Chapdaniel, A. (2016). A new modeling approach for adding value to agri-food chains. 149th Seminar "Structural Change in Agri-Food Chains: New Relations between Farm Sector, Food Industry and Retail Sector".

Fonseca, L., and Azevedo A. (2020). "COVID- 19: outcomes for Global Supply Chains", Management \& Marketing. Challenges for the Knowledge Society, Vol. 15, No. Special Issue, 424-438, DOI: 10.2478/mmcks-2020-0025.

Forbes, N., \& Wield, D. (2002). From Followers to Leaders: Managing Technology and Innovation. Routledge.

Galán, A. A., Cabañas, J. G., Cuevas, Á., Calderón, M., \& Rumin, R. C. (2019). Large-Scale Analysis of User Exposure to Online Advertising on Facebook, IEEE Access, 7, 11959-11971, https://doi.org/10.1109/ACCESS.2019.2892237.

Govindan, K. (2018). Sustainable consumption and production in the food supply chain: A conceptual framework, International Journal of Production Economics, 195, 419-431, https://doi.org/10.1016/j.ijpe.2017.03.003.

Grönroos, C., \& Voima, P. (2012). Critical service logic: making sense of value creation and co-creation, Journal of the Academy of Marketing Science, 41(2), 133-150, https://doi.org/ 10.1007/s11747-012-0308-3.

Hein, A., Weking, J., Schreieck, M., Wiesche, M., Böhm, M., \& Krcmar, H. (2019). Value cocreation practices in business-to-business platform ecosystems, Electronic Markets, https://doi.org/10.1007/s12525-019-00337-y.

Ignat, R., \& Constantin, M. (2020). Short-Term Effects of COVID-19 Pandemic on Agri-Food Value Chains in Romania, Proceedings of the 3rd International Conference on Economics and Social Sciences, 578-588, https://doi.org/10.2478/9788395815072-058.

Jayashankar, P., Johnston, W. J., Nilakanta, S., \& Burres, R. (2019). Co-creation of value-in-use through big data technology - a B2B agricultural perspective, Journal of Business \& Industrial Marketing, 35(3), 508-523, https://doi.org/10.1108/jbim-12-2018-0411.

King, L., Stark, J. F., \& Cooke, P. (2016). Experiencing the Digital World: The Cultural Value of Digital Engagement with Heritage, Heritage \& Society, 9(1), 76-101, https://doi.org/ 10.1080/2159032x.2016.1246156.

Kotler, P., Keller, P., Ang, S. H., Leong, S. M., \& Tan, C. T. (2006), Marketing and Management: An Asian Perspective. Prentice Hall, Singapore.

Kovalenko, A., and Kuzmenko, Y. (2020). "Online marketing impact on micro-enterprises: an insight through visibility in search engines", Management \& Marketing. Challenges for the Knowledge Society, 15(1), 38-58, DOI: 10.2478/mmcks-2020-0003.

Kumar, V., Aksoy, L., Donkers, B., Venkatesan, R., Wiesel, T., \& Tillmanns, S. (2010). Undervalued or Overvalued Customers: Capturing Total Customer Engagement Value, Journal of Service Research, 13(3), 297-310, https://doi.org/10.1177/1094670510375602.

Lidl (2021). Sustainability Report. https://corporate.lidl.co.uk/sustainability.

Lind, P. (2005). Competitiveness through Increased Added Value: A Challenge for Developing Countries, Journal of Comparative International Management, 8(1).

Lusch, R. F., \& Nambisan, S. (2015). Service Innovation: A Service-Dominant Logic Perspective. 
MIS Quarterly, 39(1), 155-176, https://doi.org/10.2307/26628345.

Minten, B., Murshid, K. A. S., \& Reardon, T. (2013). Food Quality Changes and Implications: Evidence from the Rice Value Chain of Bangladesh. World Development, 42, 100-113, https://doi.org/10.1016/j.worlddev.2012.06.015.

Myllylahti, M. (2018). An attention economy trap? An empirical investigation into four news companies' Facebook traffic and social media revenue, Journal of Media Business Studies, 15(4), 237-253, https://doi.org/10.1080/16522354.2018.1527521.

PICBE |

Newell, P., \& Mulvaney, D. (2013). The political economy of the "just transition." The Geographical Journal, 179(2), 132-140, https://doi.org/10.1111/geoj.12008.

Nguyen, T. A. T., \& Jolly, C. M. (2020). Global value chain and food safety and quality standards of Vietnam pangasius exports, Aquaculture Reports, 16(100256), 100256. https://doi.org/ 10.1016/j.aqrep.2019.100256.

Paun, C., Ivascu, C. (2021). "The impact of EU's financial support on the agriculture's development: a panel data analysis", Management \& Marketing. Challenges for the Knowledge Society, 16(2), 86-100, DOI: 10.2478/mmcks-2021-0006.

Piller, F. T., Vossen, A., \& Ihl, C. (2012). From Social Media to Social Product Development: The Impact of Social Media on Co-Creation of Innovation, Die Unternehmung, 65(1).

Porter, M. E. (1985). The Competitive Advantage: Creating and Sustaining Superior Performance. In Hbs.edu. NY: Free Press. Ritter, T., \& Pedersen, C. L. (2019). Digitization capability and the digitalization of business models in business-to-business firms: Past, present, and future, Industrial Marketing Management, https://doi.org/10.1016/j.indmarman.2019. 11.019 .

Rodgers, S., \& Thorson, E. (2018). Special Issue Introduction: Digital Engagement with Advertising, Journal of Advertising, 47(1), 1-3, https://doi.org/10.1080/00913367.2017. 1414003.

Sahut, J., Dana, L., \& Laroche, M. (2019). Digital innovations, impacts on marketing, value chain and business models: An introduction. Canadian Journal of Administrative Sciences / Revue Canadienne Des Sciences de L'Administration, 37(1), 61-67, https://doi.org/ 10.1002/cjas.1558.

Saurabh, S., \& Dey, K. (2020). Blockchain technology adoption, architecture, and sustainable agrifood supply chains, Journal of Cleaner Production, 124731, https://doi.org/10.1016/ j.jclepro.2020.124731.

Simatupang, T. M., Ginardy, R., \& Handayati, Y. (2018). New framework for value chain thinking. International Journal of Value Chain Management, 9(3), 289-309, https://doi.org/10.1504/ IJVCM.2018.093892.

Sorensen, A., Andrews, L., \& Drennan, J. (2017). Using social media posts as resources for engaging in value co-creation, Journal of Service Theory and Practice, 27(4), 898-922, https://doi.org/10.1108/jstp-04-2016-0080.

United Nations (2015). Transforming our World: the 2030 Agenda for Sustainable Development. Varela, R. P., Balanay, R. M., \& Halog, A. (2021). Changing the Way We Produce Food: An Overview of the Current Agricultural Food Production Industry and Worldwide Trends for Sustainable Production, Climate Change and Resilient Food Systems, 205-217, https://doi.org/10.1007/978-981-33-4538-6_7.

Walters, D., Halliday, M., \& Glaser, S. (2002). Added value, enterprise value and competitive advantage, Management Decision, 40(9), 823-833, https://doi.org/10.1108/00251740210 441045 .

DOI: $10.2478 /$ picbe-2021-0075, pp. 811-823, ISSN 2558-9652|

Proceedings of the $15^{\text {th }}$ International Conference on Business Excellence 2021 
Xie, K., Wu, Y., Xiao, J., \& Hu, Q. (2016). Value co-creation between firms and customers: The role of big data-based cooperative assets, Information \& Management, 53(8), 1034-1048, https://doi.org/10.1016/j.im.2016.06.003.

Yoon, G., Li, C., Ji, Y. (Grace), North, M., Hong, C., \& Liu, J. (2018). Attracting Comments: Digital Engagement Metrics on Facebook and Financial Performance, Journal of Advertising, 47(1), 24-37, https://doi.org/10.1080/00913367.2017.1405753.

Zhao, G., Liu, S., Lopez, C., Lu, H., Elgueta, S., Chen, H., \& Boshkoska, B. M. (2019). Blockchain technology in agri-food value chain management: A synthesis of applications, challenges and future research directions, Computers in Industry, 109, 83-99, https://doi.org/10.1016/ j.compind.2019.04.002. 